UDC 330.11

DOI: $10.18524 / 2413-9998 / 2018.2(39) .144904$

\author{
I. M. Nyenno, \\ $\mathrm{PhD}$ in Economics, docent, \\ Associate professor of Department of management and innovations \\ of Odessa I. I. Mechnikov National University, \\ 24/26, Frantsuzkiy av., Odessa, 65044, Ukraine \\ e-mail: inyenno@onu.edu.ua
}

\title{
SEA TRADE PORT: BUSINESS-MODEL STRUCTURE AND SOURCE OF INNOVATION
}

The article deals with the structure of the business-model, the complementary assets are described on the case of the sea trade port as a foundation of the businessmodel creation. The complementary assets use are studied in the context of operational strategies to obtain economic rents in the case of sale; the formation of a joint venture, public-private partnerships; signing the concession lease or licensing rights of access to complementary assets.

Keywords: business-model, complementary assets, sea trade port, innovation generation.

Competitiveness increase and added values creation is a highlight of theorists and practitioners in the context of structure and principles of business organization. Business-model concept is one of the main inventions to solve this task. The most forceful, effective and long-term profitable are the organizations, which are founded on the correctly selected businessmodels with the appropriate component structure. Business-model studies were started in the 1990th. In course of time the actuality of this topic was only increasing. The business-model research is taking place with the usage of descriptive and constructive definitions. The constructive ones are concentrated on the system building (A. Osterwald, I. Pinie, N. Strekalova, T. Vashakmadze), while descriptive ones set up the characteristics of this category (R. Amitt, S. Zott, J. Linder, R. Rosenblum, G. Smith, S. Shafer). In the both cases the business-model describes the way, the company is implementing its business in order to create the added value. The range of authors considers the external impact of the economic environment on the modern business-models. They research their characteristics. The attention of such scientists as G. Chesbrough, L. Schweizer, D. Debelak, R. Sliwotskiy, L. Frolova, F. Simanovskiy is directed on the classification approaches of the business-models. One of the still unsolved tasks is the introduction of the practical approach to the business-models analysis. 
The profitability of the business model in his view is reinforced by four categories: output, which is increasing; neutralization of competitors; strategic saving; strategic flexibility. The first two categories he identifies with the monopoly. Thus he says that the purpose of the business-model is to search a real monopoly effect. Strategic savings are not savings arising from operational efficiency. However, it is the result of effective business-models in three categories: saving thank to scale; saving thank to specialization or focus; saving thank to scope. Strategic flexibility is ensured by optimum amount of product portfolio, operating liveliness and low breakeven level.

The important moment of the optimization of the existing or development of the new business-model is the determination of the form, which will be used for the visualizing. The basic blocks, that business-model consists, are constructed from the certain key elements:

1) clients: the target group of clients (for new products, services, decision); distribution and sales channels; the interaction mechanism with the target group of clients;

2) value suggestion: new products; new services; new decisions;

3 ) the system of value creation: chain of value creation (for new products, services, decision); infrastructure, necessary to create the value; cooperation or partnership model for clients or suppliers; technological platform;

4) financial model: cost structure; income structure; financial flows scheme.

The matrix, which consists of these building blocks, is presented for the sea trade port on the Figure 1.

This study is based on fragments of existing theories, but is beyond their frameworks. The scientific contribution of the author is suggestion the methodology of dynamic and comparative analysis of the sea trade ports business-models. The present approach may be the justification for transformation and configuration of business-models changes. Prospects of the futher research is the analysis of business-models in various industires by determining the list of activities that are performed to create added value.

Etymological expression of the term "complementarity" is displayed the Latin word "complementum" that means complement. In economics, this term was used first by Menger K., Austrian School of Economics [1, p. 480]. In his book "Principles of Political Economy" Menger K. distributed economic benefits in order to substantiate the principle of complementarity and the production of goods of different orders. In 
particular, for the production of bread (first-order benefit) it is necessary to use the second-order benefits (water, fuel). Even the presence of third-order benefits will not allow producing bread. Wieser F. in his research "Theories of social economy" was developing these ideas. He believed that factors of production are complementary, but none of them - labor, land, capital creates revenue by itself. For the smooth conduct production manufacturer must be able to make up his mind about the extent to which each of the participating interacting factors in creating income in each case. He must be able to determine which part of the whole product meets the productive forces [2, p. 490].

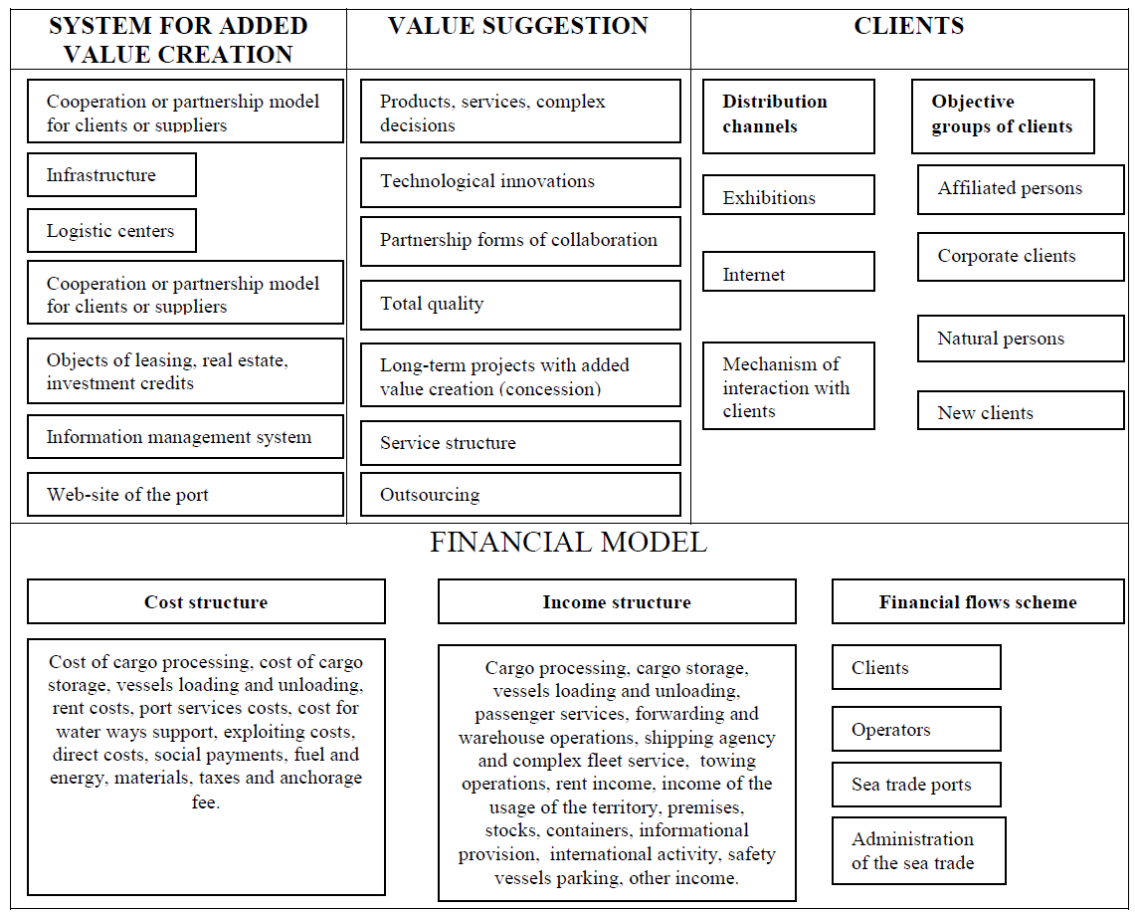

Figure 1. Business-model visualization upon four blocks Sea trade port case

Source: own development.

Three types of the complementarity can be distinguished by the purpose of use:

1) reinforcing complementarity - are assets involved to the same direction of work in the technological chain, such assets may not be mutually commute. 
2) flanking complementarity - achieving of the planned purposes, which is dependent on the conditions that are supportive between different assets (for example, the availability of intellectual property, technologies).

3) compensation complementarity - is the situation where the use of an asset blocks the effects caused by other asset (eg, social security of the staff) [3, p. 14].

The theory of complementary assets is based on research of Milgrom P. and Roberts J. "The economy of modern manufacturing: technology, strategy and organization" [4, p. 513], which introduced this concept. Initially it was used for the market in the following sense: products are considered complementary if the price reduction of one of them leads to increased demand for another, if the increase in sales of one of them increases the marginal return on another (for example, cars and tires). Their concept covered by this definition both: resources and assets. Complementary assets are those assets for which the following condition is implemented: the effect of investments in one asset in the absence of investment in the other is zero or negative. Thus, for a positive outcome the simultaneous development and use of complementary assets is required. Complementary assets should be developed together. Based on the definition it can be stated that for an enterprise the degree of use of outsourcing, lease or concession of assets is inversely proportional to the degree of their complementarity. Activities or business-processes that are fundamental to generate revenue and value added should be realized within the enterprise, oriented to the long term development and synergy.

Teece $\mathrm{Dj}$. considered that ownership for the complementary assets define the subject who would receive the profits [5, p. 301].

Teece $\mathrm{Dj}$. considered that ownership for the complementary assets define the subject who would receive the profits [6, p. 301].

Complementary advantages lead to strategic synergy. The interaction of complementary assets within the enterprise or partnership creates added value for the consumer, increases the benefit of the assets owners. It is possible the allocation of costs, which increases profitability. If the complementary assets are unique, it leads to a monopoly position of its holders. Enterprises achieve sustainable development if they do not only possess or acquire complementary assets, but also protect them and access to them. An example of this approach is the functioning of hierarchical structures, diversified or connected through the technology chain. If the assets owner is a partner, it is mandatory to establish monitoring of its behavior and to ensure the presence of certain restrictions on use of the know-how, trade secrets, knowledge or technology in the business model [7, p. 91]. The need for systematic 
acquisition of complementary assets (resources) carries out the negative impact on the company, because the owners (sellers) will always seek to obtain of value created for consumers. This procurement within the business model should be provided in the form of gradual redemption or through legal protection of intellectual property (lease, concession, joint patent, obtain a general license).

Research of the complementary assets is related to the search for answers to questions about the optimal mix of resources for the creation of added value. Although complementary assets are considered in terms of the positive impact they can have the opposite effect, particularly on investment. On the one hand, they can reduce costs of the enterprise, on the other, can lead to flexibility restrictions. Complementary assets enable protection from major assets from the competitors. Possibilities to achieve organizational synergies of tangible and intangible assets increased in the presence of complementary ones. Investment in complementary assets may be irreversible. As the study showed [8, p. 26] for tangible assets the decision to start or stop investment does not depend on intangible assets and is based on fixed costs. The combination of assets that includes complementaries in the context of the impact on the investment progress shows that the historical evolution of the company, which is the owner of complementary assets may limit its strategic choice [9, p. 37].

According to Teece $\mathrm{Dj}$., innovation that embodies the know-how should be used together with the other assets or ability to generate profits in the market. These assets are the supply chain, marketing, brand. The process of using complementary assets pursues goals of consuming know-how, which are embodied in innovations, by final consumer. This goal achieving is possible under the following conditions:

1) Complementary assets correspond to innovation. The enterprise must obtain exclusive access to the assets and create barriers for those from whom there is demand for them.

2) Company gets first right to the assets use and constantly improves product (service) or creates new products (services) instead of the old ones.

There are complementary assets of market and non-market origins. Complementary assets market origin - are local expertise, experience and expertise with consumers distribution brand. By the complementary assets are non-market origin of subsidies, tax exemptions, preferences, licenses, political ties [10, p. 653-654].

Complementary assets of the non-market origins arise due to state support, for instance in the state-owned enterprises. They are a source of 
market power to their owners and the purpose of the competition for those who want to own them. Whatever type of complementary assets derived or dependent (positive) from the core assets. Their effectiveness depends on their organization of property relations. Possible is the form in which one person possess the basic and complementary assets. Otherwise, various forms of joint ownership are used, such as forming partnerships, joint venture. Joint ownership is expedient if the maintenance and development of complementary assets is expensive and uneconomical for the owner of the core main assets, or if ownership of complementary assets should remain under state for strategic purposes.

The institutional environment can be highly or partially restricted in terms of the presence of barriers and rules on access to the market of entities through the state regulation. In a highly restricted environment entry barriers to new market is difficult to overcome because of the national protectionism. Preferential access to complementary assets are primarily opened for the state-owned enterprises or branch of central state-owned enterprises (e.g. Administration of sea ports of Ukraine and its affiliates). The implementation of this right provides monopoly and demand for complementary assets owner services. If the development of the company needs to attract additional assets, there is a need of the formation mechanisms of attraction with simultaneous protecting of the existing complementary assets. Possible forms of involvement can be: buying and selling of complementary assets to obtain economic rents in the case of sale; the formation of a joint venture, public-private partnerships; signing the concession lease or licensing rights of access to complementary assets (see fig. 2):

\begin{tabular}{|c|c|c|}
\hline 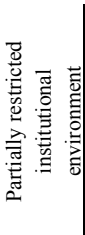 & $\begin{array}{l}\text { Quadrant } 3 \\
\text { Forming of the joint enterprise with foreign capital } \\
\text { with the ownership right on the complementary assets } \\
\text { Sequences: } \\
\text { Creation of the new legal entity with foreign capital } \\
\text { and ownership roght on the specialized } \\
\text { complementary assets }\end{array}$ & $\begin{array}{c}\text { Quadrant } 4 \\
\text { Forming of the strategic alliance with the access right on the } \\
\text { complementary assets through concession } \\
\text { Sequences: } \\
\text { Investors receibe the partial access to the generic } \\
\text { complementary assets because of the input of the own } \\
\text { complementary assets to the enterprise functioning } \\
\text { (technology, expertise, financing) }\end{array}$ \\
\hline 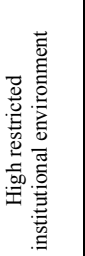 & $\begin{array}{c}\text { Quadrant } 1 \\
\text { Forming of the state-private partnership } \\
\text { with the ownership right } \\
\text { on the complementary assets } \\
\text { Sequences: } \\
\text { The corporate enterprise should be crated with } \\
\text { partially private capital of the country residents in } \\
\text { order to receive the joint right to use the specialized } \\
\text { complementary assets }\end{array}$ & $\begin{array}{l}\text { Quadrant } 2 \\
\text { Negotiating a license agreement, } \\
\text { receipt of the preference, } \\
\text { Sequences: } \\
\text { outsourcing for the complementary assets use } \\
\text { Investors receives the access to the generic complementary } \\
\text { assets through outsourcing woth the right to use them by } \\
\text { concession }\end{array}$ \\
\hline
\end{tabular}

Figure 2. Complementary assets access formation

Source: own development. 
Generic complementary assets - are the type of commodity assets, with which can be carried out operations in the commodity market. Specialized complementary assets - are the unique assets that are critical to be able to sell a product or service $[11, \mathrm{p}$. 52]. According to Teece J., marketing, competitive production, after-sales support is always needed to reach the final consumer. These services are of complementary assets. He divides three types of the complementary assets: generic, specialized, co-specialized [12, p. 288-289].

Generic complementary assets should not only be tailored to a specific product / service, because they are often used in the market based on competition (such as it is - the necessary equipment).

Specialized complementary assets are characterized by one-sided dependence on primary product (service) sales. Joint specialized complementary assets inherent in the bilateral relationship. In particular, the reputation of the company is specialized complementary assets. Additional features exterior design of the car is a joint specialized complementary asset, depending on the power car repairs. List of specialized and generic examples of complementary assets in commercial sea port is provided in the table below.

Table 1

\section{Complementary assets of the sea trade port}

\begin{tabular}{|c|c|}
\hline Specialized complementary assets & Generic complementary assets \\
\hline $\begin{array}{ll} & \text { reputation; } \\
- & \text { brand; } \\
- & \text { formed clusters; } \\
- & \text { distribution network; } \\
- & \text { specialists experience and qualification; } \\
- & \text { expertise; } \\
- & \text { sea port community; } \\
- & \text { informative databases. }\end{array}$ & $\begin{array}{ll}- & \text { infrastructure; } \\
\text { - } & \text { equipment; } \\
\text { - } & \text { control and checkpoint capacities (customs control); } \\
\text { - } & \text { computer and automatization systems; } \\
\text { - } & \text { social networks, ERP-networks; } \\
\text { - } & \text { agreements with the state and municipality. }\end{array}$ \\
\hline
\end{tabular}

Source: own development.

Teece $\mathrm{Dj}$. considers that the acquisition of specialized complementary assets requires long-term investments. These assets often difficult to imitate. So that they become a source of competitive advantage. The cost of specialized complementary assets can only increase, because even the arrival of new actors creates a demand on them and requires access for them. At the same time, ownership of complementary assets prevents the lack of demand for basic core assets, because of the stimulating their updates on a competitive basis [13, p. 130]. The mechanism of this update is that the owners collect complementary assets (assign) rents from manufacturers of 
new products / services that appear on the market because of complementary assets access.

Rothaermel F. T. and Hill Charles W. L. prove that the new company in the industry initiate technological competence discontinuities discontinues in the market. They act with created competitive advantage in order to obtain the benefits of the sector actors, often causing by Shumpeterian process of creative destruction, a term he introduced to describe the life cycle of companies [14, p. 54]. Changing the balance of power and the dissolution of existing enterprises is particularly intense when complementary assets held by market actors are generic. In this case, new market players are able to compete for complementary assets for the right to use them with higher profitability. Existing businesses can demonstrate a lack of flexibility and progress in the technologies of use of generic complementary assets in the absence of seeking perfection in terms of a monopoly position. At the same time the new companies, which follow the purpose of pursuing access to complementary assets show strong motivation to capture this monopoly.

The rationale dignity of their competitive position is a potential accumulation of higher monopoly rents from the use of complementary assets than in existing businesses through innovation or use of new, more profitable business model. Examples of technological discontinuity is the transition from the use of vacuum tubes to transistors, transistors and later on semiconductors. Another example is the emergence of electronic calculators, which destroyed a direction competences granted precursors within the electromechanical paradigm. In particular, electronic calculators devalued assets of electromechanical complementary competencies, because the new devices did not require specialized service and distribution by professionals.

That is, if the new market actors have access to generic complementary assets which will be additional for major innovation assets, this decline will lead a group decline of acting market subjects, the last owners of common complementary assets. There are exceptions to these cases, which suggests that technological discontinuity does not always lead to the domination of new markets. That ownership right of complementary assets is crucial in the matter of who will receive profits from the production of products or provision of services. Even the existence of this ownership right increases the likelihood that an active market master of the field, which emerged as a new line or reserve its efficiency.

The probability is the higher the more specialized are the complementary assets. M. Tripsas in his study on the example of typewritten enterprises proved that complementary assets owners may even benefit from 
technological discontinuities if their complementary assets are specialized. In this case, their value only increases [15, p. 144]. This effect is particularly pronounced in the condition of low protection of intellectual property or strong sustainable protectionism of owners of complementary assets. Under such conditions, the availability of ownership of specialized complementary assets enables innovative assign rents for new market players [16, p. 302]. It is possible the scenario implementation of cooperation between new and existing entities in which there is a symbiosis of complementary assets and positive new fixed assets. Through this cooperation, on the one hand, a new high added value is created, and on the other hand, a competition in the distribution of this cost arises. Besides the owner of specialized complementary assets as a participant of such an alliance is obtaining stronger market position [17, p. 155]. Furthermore, if the system of sales and other marketing tools of the holder of specialized complementary assets are not sensitive to the effects of changes arising as a result of new inventions, created by existing businesses value can be increased even without forming an alliance for specialized complementary assets become more attractive to new market players. Specifically, from new market players the demand for specialized complementary assets of existing enterprises arises. Their assets can be combined with a new asset to improve the profitability of both players [18, p. 20-23].

In particular, ownership of specialized complementary assets has allowed pharmaceutical companies to establish alliances with biotech companies. This act not only helped them to adapt to innovation, but gave the possibility if the accumulation of innovation rents [19, p. 1245].

Thus, in terms of technological gaps cooperation of new and existing market players strengthens the market position of the actors, if it has specialized complementary assets, as this allows him to assign innovation rents by combining with the new subjects of innovative system.

Complementary assets - are the assets that are mutually combinatorial and complete each other, than achieve a synergistic effect for access to the consumer in terms of highest return for providing the ability to create added value for the consumer. The result of their interaction is the development of partnerships within the value chain of product/service delivery. The subject of partnerships is access to complementary assets.

Reinforcing, flanking and compensation complementarity can be distinguished. By origin distinguish between market and non-market complementary assets; the conformity of a product or service - specific and general. Reinforcing, flanking and compensational complementaruty can be 
distinguished. By the origin there are market and non-market complementary assets; by the correspondence to the product or service - generic and specialized.

The following properties are inherent for the complementary assets:

Complementary assets inherent to the following properties:

1. Synergetic effect is possible to be provided in the case of the simultaneous development of complementary assets.

2. The uniqueness of the complementary assets leads to a monopoly of their owner.

3. The ownership right on the complementary assets is crucial to determining the recipient of the income.

To receive the access right to the complementary assets is happening in determination of their kind and is possible through the formation of the: joint enterprise, state-private partnership, strategic alliance and licensing, preferential or outsourcing agreements for the complementary assets usage. According to the business-model definition the advisability of engaging the complementary assets as a basis for business-model formation is justified because of their ability to provide the monopolistic position of the complementary assets owner. The added value, demanded by the customer, is created as a result of synergetic interaction of complementary assets. Thus the resource application is taking place in the conditions of the added value increase, which is created by the enterprise.

The further research in this direction is presented in the figure 3.

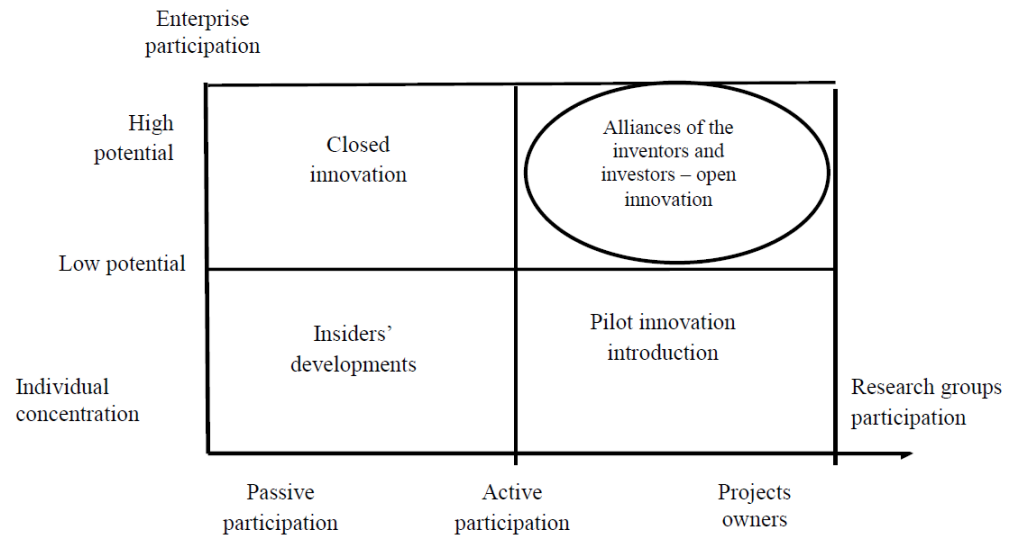

Figure 3. Matrix of innovation generation

Source: own development. 
According to the law of the system theory, innovative system, like any other system should not be closed or isolated. The positive effect of the system components is manifested its arithmetic properties through multiplication effect. According to another principle of the same theory: "it is impossible to affect the system, while being inside the system". That's why the innovation that is the foundation of business -model should initiate the multiplied positive effects of its introduction. Multidimensional innovation, which is a combination of market innovation, product innovation and arised innovation of the business-model can be a catalyst to create and increase the added value of the enterprises.

\section{References}

1. Menger, K. (1992). The Foundation of political economy. The Austrian school in political economy. Moscow : Economy.

2. Viser, F. (1992). Theory of public economy. The Austrian school in political economy. Moscow : Economy.

3. Abuzyarova, M. I. (2015). The complementarily of companies' assets as an effective tool for managing innovation projects. London Journals in Economics, Marketing, Finance, Business and Innovation, Vol. 2. pp. 7-17.

4. Milgrom, P. \&, Roberts, J. (1990). The Economics of Modern Manufacturing: Technology, Strategy, and Organization. The American Economic Review, № 80 (3), pp. 511-528.

5. Teece, Dj. (1986). Profiting from technological innovation: implications for integration, collaboration, licensing and public policy. Research Policy, № 15 , pp. 285-305.

6. Teece, Dj. (1986). Profiting from technological innovation: implications for integration, collaboration, licensing and public policy. Research Policy, № $15, \mathrm{pp}$. 285-305.

7. Hamel, G. (1991). Learning in international alliances. Strategic Management Journal, Vol. 12, pp. 83-103.

8. Pastor-Agustín, G., Marisa Ramírez-Alesón, M. \& Espitia-Escuer, M. (2011). Complementary Assets and Investment Decisions. Emerging Markets Finance \& Trade, November-December, Vol. 47, Supplement 5, pp. 25-39.

9. Pastor-Agustín, G., Marisa Ramírez-Alesón, M. \& Espitia-Escuer, M. (2011). Complementary Assets and Investment Decisions. Emerging Markets Finance \& Trade, November-December, Vol. 47, Supplement 5, pp. 25-39.

10. Pek-Hooi, S.\& Jiang, Y. (2010). Institutional environment and complementary assets: Business strategy in China's 3G development. Asia Pacific Journal of Management, December, pp. 646-675.

11. Rothaermel, F. T. \& Hill Charles, W. L. (2005). Technological discontinuities and complementary assets: a longitudinal study of industry and firm performance. Organization Science, Vol. 16, № 1, January-February, pp. 52-70. 
12. Teece, $\mathrm{Dj}$. (1986). Profiting from technological innovation implications for integration, collaboration, licensing and public policy. Research Policy, № 15 , pp. 285-305.

13. Tripsas, M. (1997). Unraveling the process of creative destruction: Complementary assets and incumbent survival in the typesetter industry. Strategic Management Journal, № 18, pp. 119-142.

14. Rothaermel, F. T. \& Hill Charles, W. L. (2005). Technological discontinuities and complementary assets: a longitudinal study of industry and firm performance. Organization Science, Vol. 16, № 1, January-February, pp. 52-70.

15. Tripsas, M. (1997). Unraveling the process of creative destruction: Complementary assets and incumbent survival in the typesetter industry. Strategic Management Journal,. № 18, pp. 119-142.

16. Teece, $\mathrm{Dj}$. (1986). Profiting from technological innovation implications for integration, collaboration, licensing and public policy. Research Policy, № 15 , pp. 285-305.

17. Lerner, J. \& Merges, R. (1998). The control of technology alliances: An empirical analysis of the biotechnology industry. Journal of Industrial Economics, № 46, pp. 125-156.

18. Teece, $\mathrm{Dj}$. (1992). Competition, cooperation, and innovation. Organizational arrangements for regimes of rapid technological progress. Journal of Economic Behavior Organisations, № 18, pp. 1-25.

19. Rothaermel, F. T. (2001). Complementary assets, strategic alliances, and the incumbent's advantage: An empirical study of industry and firm effects in the biopharmaceutical industry. Research Policy, № 30, pp. 1235-1251.

\section{И. М. Ненно,}

Стаття надійшла 12.07.2018 p.

кандидат экономических наук, доцент

доцент кафедры экономики и управления, Одесского национального университета имени И. И. Мечникова, Французский бульвар, 24/26, г. Одесса, 65058, Украина, e-mail: inyenno@onu.edu.ua

\section{МОРСКОЙ ТОРГОВЫЙ ПОРТ: СТРУКТУРА БИЗНЕС МОДЕЛИ И ИСТОЧНИК ЕЕ ИННОВАЦИЙ}

В статье рассматривается структура бизнес-модели, дополняющие активы описываются в случае морского торгового порта в качестве основы создания бизнес-модели. Изучение взаимодополняющих активов изучается в контексте операционных стратегий для получения экономической ренты в случае продажи; создание совместного предприятия, государственно-частного партнерства; подписание аренды концессии или лицензирование прав доступа к дополнительным активам.

Ключевые слова: бизнес-модель, комплементарные активы, морской торговый порт, генерация инноваций. 


\section{I. М. Нснно,}

кандидат економічних наук, доцент кафедри економіки та управління

Одеського національного університету імені I. I. Мечникова вул. Французький бульвар, 24/26, м. Одеса, 65058, Україна, e-mail: inyenno@onu.edu.ua

\section{МОРСЬКИЙ ТОРГОВЕЛЬНИЙ ПОРТ: СТРУКТУРА БІЗНЕС-МОДЕЛІ ТА ДЖЕРЕЛО ЇЇ ІННОВАЦІЙ}

У статті розглянута структура бізнес-моделі, описуються додаткові активи на випадок морського торговельного порту як основи створення бізнес-моделі. Використання додаткових активів вивчається в контексті операційних стратегій для отримання економічної ренти у випадку продажу; формування спільного підприємства, державно-приватного партнерства; підписання концесійного лізингу або ліцензування прав доступу до додаткових активів. Визначено властивості комплементарних активів, зокрема: синергетичний ефект можна забезпечити у випадку одночасного розвитку додаткових активів; унікальність додаткових активів призводить до монополії власника; право власності на додаткові активи має вирішальне значення для визначення одержувача доходу.

Спеціалізованими комплементарними активами морського порту визначено: репутацію; бренд; сформовані кластери; мережи дистрібуції; досвід та кваліфікація спеціалістів; експертиза; громада морського порту; інформаційні бази даних. Загальними додатковими активами пропонується розглядати: інфраструктуру; обладнання; контрольні та контрольно-пропускні потужності (митний контроль); комп'ютери та системи автоматизації; соціальні мережі, ERPмережі; угоди з державою та муніципалітетом.

Отримання права доступу на додаткові активи відбувається залежно від їхнього роду і можливо завдяки формуванню спільного підприємства, державноприватного партнерства, стратегічного альянсу та ліцензування, угод про надання пільгових або аутсорсингових послуг для використання додаткових активів. Відповідно до визначення бізнес-моделі, доцільність залучення додаткових активів як основи формування бізнес-моделі є обгрунтованою через їх здатність надавати монопольне становище власника додаткових активів. Додаткова вартість, яку вимагає замовник, створюється внаслідок синергетичної взаємодії додаткових активів. Таким чином, застосування ресурсу відбувається в умовах збільшення доданої вартості, яка створюється підприємством.

Ключові слова: бізнес-модель, комплементарні активи, морський торговельний порт, генерація інновацій. 


\section{Список використаної літератури}

1. Menger K. The Foundation of political economy. The Austrian school in political economy / K. Menger. - Moscow : Economy, 1992. - 496 p.

2. Viser F. Theory of public economy. The Austrian school in political economy / F. Vizer. - Moscow : Economy, 1992. - 496 p.

3. Abuzyarova M. I. The complementarily of companies' assets as an effective tool for managing innovation projects / M. I. Abuzyarova // London Journals in Economics, Marketing, Finance, Business and Innovation. - 2015. Vol. 2. - P. 7-17.

4. Milgrom P. The Economics of modern manufacturing: technology, strategy, and organization / P. Milgrom, J. Roberts // The American Economic Review. - 1990. - № 80 (3). - P. 511-528.

5. Teece Dj. Profiting from technological innovation: implications for integration, collaboration, licensing and public policy / Dj. Teece // Research Policy. - 1986. - № 15. - P. 285-305.

6. Teece Dj. Profiting from technological innovation: implications for integration, collaboration, licensing and public policy / $\mathrm{Dj}$. Teece // Research Policy. - 1986. - № 15. - P. 285-305.

7. Hamel G. Learning in international alliances / G. Hamel // Strategic Management Journal. - 1991. - Vol. 12. - P. 83-103.

8. Pastor-Agustín G. Complementary Assets and Investment Decisions / G. Pastor-Agustin, M. Marisa Ramirez Alison, M. Espita-Escuer // Emerging Markets Finance \& Trade. - November-December 2011. - Vol. 47. Supplement 5. - P. 25-39.

9. Pastor-Agustín G. Complementary Assets and Investment Decisions / G. Pastor-Agustin, M. Marisa Ramirez Alison, M. Espita-Escuer // Emerging Markets Finance \& Trade. - November-December 2011. - Vol. 47. Supplement 5. - P. 25-39.

10. Pek-Hooi S. Institutional environment and complementary assets: Business strategy in China's 3G development / S. Pek-Hooi, Y. Jiang // Asia Pacific Journal of Management. - December 2010. - P. 646-675.

11. Rothaermel F.T. Technological discontinuities and complementary assets: a longitudinal study of industry and firm performance / F. T. Rothaermel, W. L. Hill Charles // Organization Science. - 2005. - Vol. 16. - № 1. - P. 52-70.

12. Teece Dj. Profiting from technological innovation implications for integration, collaboration, licensing and public policy / $\mathrm{Dj}$. Teece // Research Policy. - 1986. - № 15. -P. 285-305.

13. Tripsas M. Unraveling the process of creative destruction: Complementary assets and incumbent survival in the typesetter industry / M. Tripsas // Strategic Management Journal. -1997. - № 18. - P. 119-142.

14. Rothaermel F. T. Technological discontinuities and complementary assets: A Longitudinal Study of Industry and Firm Performance / F. T. Rothaermel, W. L. Hill Charles // Organization Science. - 2005. - Vol. 16. - № 1. - P. 52-70.

15. Tripsas M. Unraveling the process of creative destruction: Complementary 
assets and incumbent survival in the typesetter industry / M. Tripsas // Strategic Management Journal. - 1997. - №18. - P. 119-142.

16. Teece Dj. Profiting from technological innovation: Implications for integration, collaboration, licensing and public policy / $\mathrm{Dj}$. Teece // Research Policy. - 1986. № 15. - P. 285-305.

17. Lerner J. The control of technology alliances: An empirical analysis of the biotechnology industry / J. Lerner, R. Merges // Journal of Industrial Economics. - 1998. - № 6. - P. 125-156.

18. Teece $\mathrm{Dj}$. Competition, cooperation, and innovation. Organizational arrangements for regimes of rapid technological progress/ $\mathrm{Dj}$. Teece // Journal of Economic Behavior Organisations. - 1992. № 18. - P. 1-25.

19. Rothaermel F. T. Complementary assets, strategic alliances, and the incumbent's advantage: An empirical study of industry and firm effects in the biopharmaceutical industry / F. T. Rothaermal // Research Policy. 2001. - № 30. - P. 1235-1251. 